\title{
High Ki67 proliferation index but not cell-of-origin subtypes is associated with shorter overall survival in diffuse large B-cell lymphoma
}

\author{
Feras Zaiem, Rada Jerbi ${ }^{1}$, Omar Albanyan², Jordyn Puccio, Zyad Kafri , Jay Yang ${ }^{2}$, Ali M. Gabali \\ Hematopathology department, Barbara Ann Karmanos Center and Wayne State University School of Medicine, Detroit, Michigan, USA, \\ ${ }^{1}$ Pathology Department, Christ Hospital, Cincinnati, Ohio, USA, ${ }^{2}$ Division of Hematology/Oncology, Barbara Ann Karmanos Center and Wayne \\ State University School of Medicine, Detroit, Michigan, USA, ${ }^{3}$ Division of Hematology and Oncology, St. John Hospital and Medical Center, \\ Detroit, Michigan, USA
}

\begin{tabular}{|c|}
\hline Access this article online \\
\hline Website: www.avicennajmed.com \\
\hline DOI: 10.4103/ajm.ajm_81_20 \\
\hline Quick Response Code: \\
\hline
\end{tabular}

\begin{abstract}
Background: CD10, BCL6, and MUM1 are commonly used immunohistochemical stains for classifying diffuse large B-cell lymphoma (DLBCL), which is useful in predicting outcome. Conflicting reports of the prognostic value of other markers such as BCL2, CD23, and Ki67 proliferation index have been reported. Our objective was to correlate these immunostains and Hans classification with response to therapy and overall survival. Materials and Methods: A retrospective study of patients diagnosed with DLBCL from 2008-2014 at a tertiary-care cancer hospital. The slides with the IHC stains were reviewed by two independent pathologists. The clinical outcomes-assessed independently - were response to therapy and overall survival. The treatment response evaluation was based on the new Lugano classification. Statistical analyses were conducted using the Fisher's exact test and Kaplan-Meier survival curves. Significance was set at $P<0.05$. Results: Forty-one patients were included in the study with a known Hans classification, available clinical data, and at least 5-year follow-up. CD10 immunostain was reported in all patients, whereas CD23 was the least reported in only four patients. No significant association was observed between CD10, BCL6, MUM1, BCL2, and both Response to therapy and overall survival. Owing to few cases reported CD23 immunostain, further analysis of association is not reported. High Ki67 proliferative index of $>80 \%$ was statistically significantly associated with shorter overall survival and not statistically significant associated with no response to therapy. Hans classification subtypes were not predictive in regard to therapy response. Conclusion: High Ki67 expression ( $>80 \%$ ) was associated with shorter overall survival in DLBCL. Hans classification subtypes were not predictive.
\end{abstract}

Key words: Activated B-cell (ABC), BCL2, BCL6, B-lymphocytes, CD10, CD23, cell-oforigin classification, diffuse large B-cell lymphoma (DLBCL), germinal center B-cell (GCB), immunohistochemistry, Ki67, MUM1, overall survival, therapy response

\section{INTRODUCTION}

Diffuse large B-cell lymphoma, non-otherwise specified (DLBCL, NOS) is the most common type of adult nonHodgkin lymphoma worldwide. ${ }^{[1]}$ The standard first-line treatment is multiagent chemoimmunotherapy such as

\footnotetext{
Address for correspondence: Dr. Ali M. Gabali,

Department of Hematopathology, Barbara Ann Karmanos Center and

Wayne State University School of Medicine,

3990, John R Street, Detroit, Michigan 48201, USA.

E-mail: Agabali@med.wayne.edu
}

This is an open access journal, and articles are distributed under the terms of the Creative Commons Attribution-NonCommercial-ShareAlike 4.0 License, which allows others to remix, tweak, and build upon the work non-commercially, as long as appropriate credit is given and the new creations are licensed under the identical terms.

For reprints contact: reprints@ medknow.com

Cite this article as: Zaiem F, Jerbi R, Albanyan O, Puccio J, Kafri Z, Yang J, et al. High Ki67 proliferation index but not cell-of-origin subtypes is associated with shorter overall survival in diffuse large B-cell lymphoma. Avicenna J Med 2020;10:241-8. 
R-CHOP (rituximab, cyclophosphamide, doxorubicin, vincristine, and prednisone). However, it is only curative in approximately $60 \%$ of patients. ${ }^{[2]}$ In patients who develop relapsed/refractory disease, stem cell transplantation (SCT) is a considered treatment but many patients are not eligible. ${ }^{[3]} \mathrm{A}$ better understanding of the pathophysiology and classification of the DLBCL may help in therapy selection and impact treatment outcomes.

Decades ago, the Kiel classification of DLBCL was based on morphology such as centroblastic, immunoblastic, and anaplastic variants, with centroblastic being the most common. ${ }^{[4]}$ This subtyping was plagued by poor intraobserver and interobserver reproducibility. In the early 2000s, immunophenotypic subtyping was reported then proposed by several groups, most commonly Hans and his colleagues in 2004 who classified DLBCL into two general categories: germinal center B cell (GCB) and activated B-cell (ABC) subtype. The current most widely used working algorithm, also known as the Hans criteria, incorporates three immunostains: cluster of differentiation 10 (CD10), B-cell lymphoma 6 (BCL6), and multiple myeloma oncogen1 (MUM1) with a cutoff of $30 \%$ to identify positivity in each. ${ }^{[5]}$ The World Health Organization (WHO) classification of hematopoietic and lymphoid tumors in $2008^{[6]}$ and later the $2016 \mathrm{WHO}$ revision $^{[1]}$ incorporated the Hans criteria as follows: GCB subtype (CD10+, BCL6+/-, MUM1 +/- and CD10-, BCL6+, MUM1-) and $A B C$ subtypes for all other interpretations ${ }^{[7]}$ [Figure 1]. GCB subtype is generally of favorable prognosis compared to $\mathrm{ABC}$ profile. ${ }^{[8]}$ However, some studies have shown conflicting results using the Hans classification and showed no significant difference in overall survival between the GCB and $\mathrm{ABC} \cdot{ }^{[7]}$ In spite of these efforts, it is not uncommon to encounter lymphomas that do not fit into any of the prescribed categories or do not manifest clinically as would be predicted according to its respective subtype. This discrepancy highlights the heterogeneous nature of large B-cell lymphomas and the need to improve our current classification and prognostication. Additional prognostic markers have been studied in the DLBCL such as BCL2, ${ }^{[9]} \mathrm{CD} 23,{ }^{[10]}$ and Ki67 ${ }^{[11]}$ with conflicting results reported in the literature.

In this study, we examined the predictive value of the Hans classification and markers in a DLBCL patient population, investigated the potential predictive value of two additional markers CD23 and BCL2, and attempted to better integrate Ki67 into the working algorithm.

\section{MATERIALS AND METHODS}

For this retrospective study (IRB 2016-207, 12/2/2016), a natural language search was performed in our database information system (Copath) to retrospectively review all adult patients diagnosed with DLBCL, NOS, during the period 2008 to 2014 at Karmanos Cancer Institute, Wayne State University, Detroit, Michigan, an academic tertiary-care cancer hospital. This particular time frame was used to limit the diagnosis and the performed immunohistochemistry (IHC) panels after the publication of the 2008 WHO classification of hematopoietic and lymphoid tumors and to allow the aimed follow-up in the study. The inclusion criteria included: DLBCL diagnosis with a known cell of origin (COO) subtype using Hans criteria, available clinical data and at least 5-year follow-up (unless limited by patient death). Cases of unclassifiable B-cell lymphoma with features intermediate between DLBCL and Burkitt lymphoma or DLBCL and classic Hodgkin lymphoma were excluded.

The tissue samples underwent a lymphoma protocol that is standardized and used in our institute. The immunohistochemical stains were performed by routine methods in the clinical laboratory. The paraffin blocks were cut at 3-4 microns, dried overnight at $60^{\circ} \mathrm{C}$, and deparaffinized in xylene. Subsequently, sections were rehydrated through graded alcohol in water. Heat-induced epitope retrieval was done automatically on Ventana Ultra BenchMark, Tucson, Arizona by heating at $95^{\prime} \mathrm{C}$ Ventana CC1 Solution at $\mathrm{pH} 8.0$ for $52 \mathrm{~min}$ for CD10, BCL6, BCL2, and CD23 and for $36 \mathrm{~min}$ for MUM 1 and Ki67. Sections were then rinsed thoroughly with water and placed in a Tris-buffered saline for $5 \mathrm{~min}$. All detection steps were done using the Ventana Ultra View Universal DAB KIT; all the aforementioned antibodies were incubated for $32 \mathrm{~min}$ at $37^{\circ} \mathrm{C}$ (on the instrument).

All cases were microscopically reviewed along with the IHC slides by two independent pathologists. IHCs of interest were CD10, BCL6, MUM1, BCL2, CD23, and Ki67. A cutoff of at least $30 \%$ expression by the neoplastic cells was considered positive. A cutoff of $80 \% \mathrm{Ki} 67$ was estimated to further divide Ki67 into low and high proliferative index. A different hematologist reviewer blinded to the morphologic and immunophenotypic findings reviewed the individual patients' electronic medical record for the clinical outcomes. The treatment response evaluation was based on new Lugano classification. ${ }^{[12]}$ Patients with deauville scores of 1,2 , or 3 by PET/CT or had regression of nodal mass to $<1.5 \mathrm{~cm}$ of longest transverse diameter by CT is considered complete response (CR). All other results were considered no response (NoR) and this included patients who failed to achieve $C R$ with the first therapy line, relapsed after first CR, developed therapy-related complications, sent to hospice, and died due to DLBCL. 
Overall survival is defined as the time from DLBCL diagnosis to death. Statistical analyses were conducted using the Fisher's exact test (two tailed) and Kaplan-Meier survival curves. Significance was set at $P<0.05$.

\section{RESULTS}

Forty-one patients with DLBCL, NOS met the inclusion criteria and were included in this study. This cohort was $44 \%$ male with a mean age of 58.2 years. Of all DLBCL cases, $59 \%$ were GCB subtype and $41 \%$ were ABC subtype. All patients were treated with curative intent with chemotherapy and/or radiation, of which $34 \%$ of patients achieved CR to therapy. The mean overall survival for all patients was 68.7 months. The description of the included patients is reported in Table 1.

\section{Response to therapy}

CD10 immunostaining was performed in all patients followed by BCL6, BCL2, and MUM1 in 32, 24, and 23 patients, respectively. The description of the results is reported in Table 2 and Figure 2. There was no association between expression of CD10, BCL6, MUM1, and BCL2 with response to therapy, $71 \%$ vs. $29 \%, P=0.51,55 \%$ vs. $45 \%, P=0.25,62$ vs. $38, P=0.41$ and $61 \%$ vs. $39 \%, P=0.67$, respectively.

CD 23 immunostaining was reported only in four patients in our cohort. Therefore, further analysis of association of CD23 staining with therapy response and overall survival is not reported owing to lack of statistical relevance.

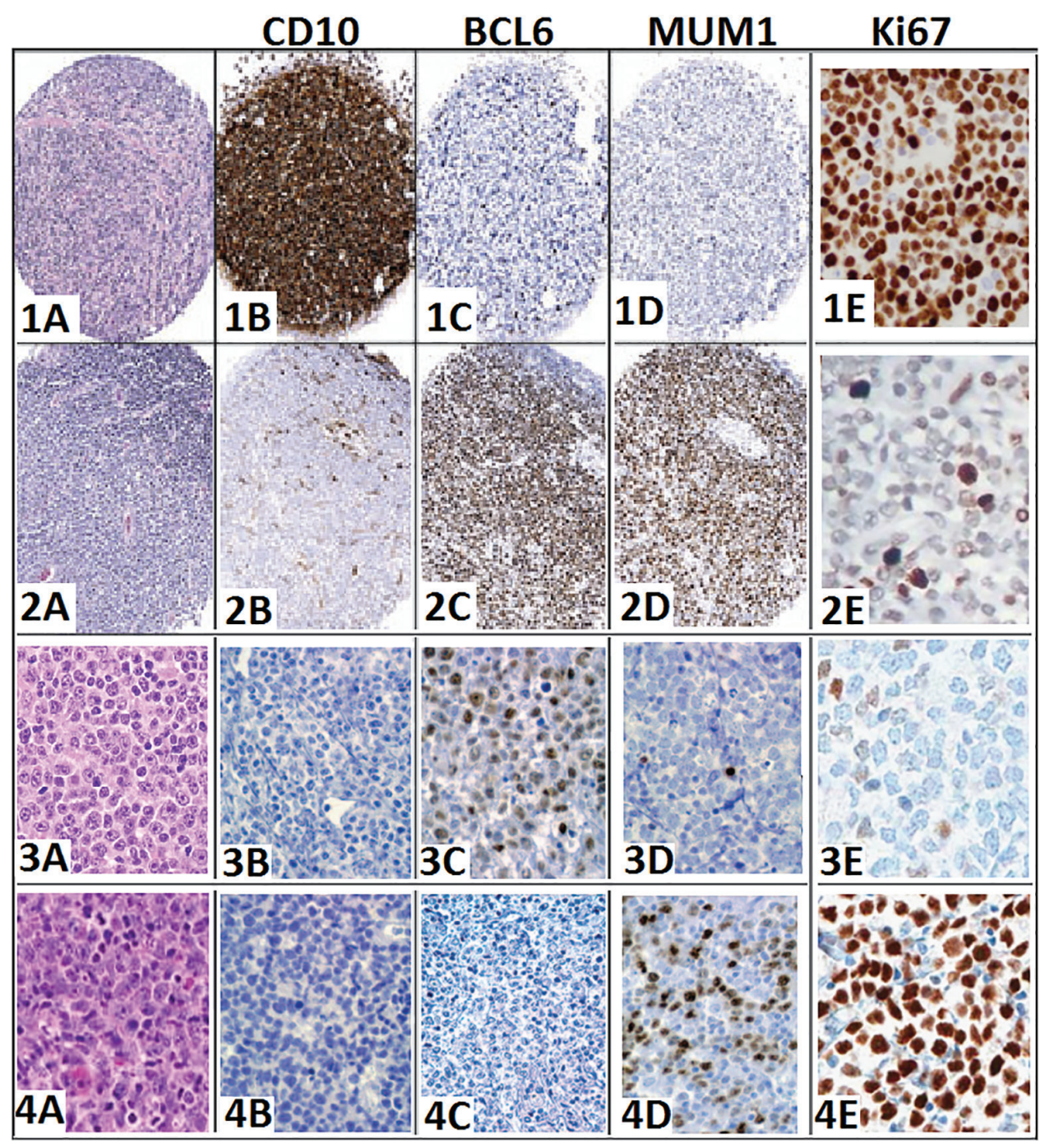

Figure 1: (1) GCB subtype DLBCL case that is CD10 positive, BCL6 negative, MUM1 negative with high Ki67 proliferation index of $>90 \%$. (2) ABC subtype DLBCL case that is CD10 negative, BCL6 positive, MUM1 positive with low Ki67 proliferation index of 10\%. (3) GCB subtype DLBCL case that is CD10 negative, BCL6 positive, MUM1 negative with low Ki67 proliferation index of $<5 \%$. (4) ABC subtype DLBCL case that is CD10 negative, BCL6 negative, MUM1 positive with high Ki67 proliferation index of $80 \%$ 
Ki67 proliferation index was reported in 38 patients. There was no association between high or low Ki67 proliferation index with NoR to therapy, Ki67 $>80 \%: 75 \%$ vs. $25 \%$ and Ki67 <80\%: $61 \%$ vs. $39 \%, P=0.48$.

Cell of origin was reported in all patients. Both GCB and ABC also showed NoR to therapy than CR (GCB: $68 \%$ vs. $32 \%$ and $\mathrm{ABC} \%: 65 \%$ vs. $35 \%)$. This association was not statistically significant $(P=1.00)$.

\section{Overall survival}

The description of the results is reported in Figure 3. Using Kaplan-Meier analysis, longer mean overall survival (months) was noted with the expression of BCL6 (70.9 vs. 30, $P=0.6$ ), MUM1 (78.3 vs. $63.3, P=0.836$ ), and BCL2 markers (71.3 vs. $33.1, P=0.384$ ). Shorter mean overall survival (months) was noted with the expression of CD10 (58.4 vs. $79, P=0.565)$, high proliferative index (Ki 67) of $>80 \%$ ( 30.7 vs. $75.9, P=0.002$ ), and GCB type rather than ABC type (58.4 vs. $79, P=0.565)$.

\section{Cases with Ki67 > 99\%}

Only three cases (7.3\%) reported a Ki67 proliferation index $>99 \%$. As expected, all were of the ABC subtype and BCL2 negative showed NoR to therapy and inferior survival.

\section{DISCUSSION}

Although the GCB subtype of DLBCL predicts better outcomes compared to $\mathrm{ABC}$ subtype, several studies

\begin{tabular}{|c|c|c|c|c|c|c|c|c|c|c|}
\hline Case no. & $\begin{array}{l}\text { Age and } \\
\text { gender }\end{array}$ & $\begin{array}{l}\text { CDI0 } \\
\text { stain }\end{array}$ & $\begin{array}{l}\text { BCL6 } \\
\text { stain }\end{array}$ & MUMI stain & BCL2 stain & CD23 stain & $\begin{array}{c}\text { ki67\% index } \\
(>80 \%)\end{array}$ & $\begin{array}{c}\text { COO } \\
\text { subtype }\end{array}$ & $\begin{array}{l}\text { Therapy } \\
\text { response }\end{array}$ & $\begin{array}{l}\text { Overall } \\
\text { survival } \\
\text { (months) }\end{array}$ \\
\hline$I$ & $68 \mathrm{~F}$ & + & NA & NA & NA & NA & - & GCB & NoR & NA \\
\hline 2 & $58 \mathrm{M}$ & + & NA & NA & NA & NA & - & GCB & NoR & 12 \\
\hline 3 & $69 \mathrm{M}$ & + & NA & NA & NA & NA & + & GCB & NoR & 3 \\
\hline 4 & $55 M$ & + & + & NA & + & NA & + & $\mathrm{GCB}$ & NoR & 12 \\
\hline 5 & $20 \mathrm{~F}$ & + & NA & NA & NA & NA & - & GCB & NoR & 124 \\
\hline 6 & $45 \mathrm{M}$ & + & NA & NA & NA & NA & - & GCB & NoR & 20 \\
\hline 7 & $49 \mathrm{M}$ & + & + & NA & - & NA & + & GCB & $C R$ & NA \\
\hline 8 & $21 \mathrm{~F}$ & + & NA & NA & NA & NA & - & GCB & NoR & 116 \\
\hline 9 & $60 \mathrm{M}$ & + & NA & NA & NA & NA & NA & GCB & NoR & 12 \\
\hline 10 & $87 \mathrm{~F}$ & + & + & NA & NA & NA & - & $\mathrm{GCB}$ & NoR & 103 \\
\hline II & $66 M$ & + & + & NA & NA & NA & + & GCB & NoR & 37.3 \\
\hline 12 & $37 \mathrm{~F}$ & - & + & - & NA & NA & - & GCB & $C R$ & 99 \\
\hline 13 & $37 M$ & + & + & NA & - & NA & + & GCB & NoR & 25.3 \\
\hline 14 & $54 \mathrm{~F}$ & - & + & + & + & NA & + & $A B C$ & NoR & 148 \\
\hline 15 & $59 \mathrm{~F}$ & - & + & + & + & NA & - & $A B C$ & NoR & 27 \\
\hline 16 & $59 \mathrm{~F}$ & - & + & + & + & NA & - & $A B C$ & NoR & 28 \\
\hline 17 & $59 \mathrm{~F}$ & + & + & & + & NA & - & $\mathrm{GCB}$ & NoR & 27 \\
\hline 18 & $58 \mathrm{~F}$ & + & + & NA & + & NA & - & GCB & $C R$ & 89 \\
\hline 19 & $58 \mathrm{M}$ & + & + & NA & NA & NA & - & GCB & NoR & 78 \\
\hline 20 & $52 \mathrm{M}$ & - & + & + & + & NA & - & $A B C$ & NoR & 25.6 \\
\hline 21 & $65 \mathrm{M}$ & - & - & NA & - & NA & - & $A B C$ & NoR & 28 \\
\hline 22 & $51 \mathrm{M}$ & + & + & - & + & NA & - & GCB & NoR & 82.5 \\
\hline 23 & $68 \mathrm{M}$ & + & + & - & - & NA & - & GCB & $C R$ & 81 \\
\hline 24 & $65 \mathrm{M}$ & - & + & + & + & NA & - & $A B C$ & NoR & 4 \\
\hline 25 & $66 \mathrm{M}$ & - & + & + & + & NA & - & $A B C$ & $C R$ & 80 \\
\hline 26 & $58 \mathrm{~F}$ & + & + & - & + & + & - & GCB & $C R$ & 54.6 \\
\hline 27 & $55 \mathrm{M}$ & + & + & - & + & - & - & GCB & $C R$ & 76 \\
\hline 28 & $70 \mathrm{~F}$ & - & + & + & - & NA & + & $A B C$ & $C R$ & 21 \\
\hline 29 & $71 \mathrm{~F}$ & + & + & - & NA & NA & + & GCB & $C R$ & 55 \\
\hline 30 & $79 \mathrm{M}$ & + & NA & NA & + & NA & - & GCB & $C R$ & 61 \\
\hline 31 & $53 \mathrm{M}$ & + & + & - & - & NA & + & GCB & NoR & 10.3 \\
\hline 32 & $58 \mathrm{M}$ & + & + & - & NA & NA & + & GCB & NoR & I \\
\hline 33 & $58 \mathrm{~F}$ & - & + & + & + & NA & - & $A B C$ & $C R$ & 59 \\
\hline 34 & $63 \mathrm{~F}$ & - & + & - & + & NA & - & GCB & CR & 58 \\
\hline 35 & $94 \mathrm{~F}$ & - & - & NA & + & + & - & $A B C$ & NoR & I \\
\hline 36 & $4 \mathrm{IF}$ & - & + & + & NA & + & - & $A B C$ & $C R$ & 64 \\
\hline 37 & $56 M$ & - & NA & + & + & NA & + & $A B C$ & NoR & 17.6 \\
\hline 38 & $55 M$ & + & + & - & + & NA & - & $\mathrm{GCB}$ & NoR & 17.3 \\
\hline 39 & $62 \mathrm{M}$ & - & + & + & NA & NA & - & $A B C$ & $C R$ & 59.5 \\
\hline 40 & $52 \mathrm{M}$ & - & + & + & NA & NA & + & $A B C$ & NoR & 7 \\
\hline 41 & $77 \mathrm{~F}$ & - & - & + & NA & NA & - & $A B C$ & NoR & 61 \\
\hline
\end{tabular}


have questioned this conclusion. ${ }^{[7,8]}$ Our results showed a nonsignificant association between GCB and shorter overall survival with no conclusive results in regard to response to therapy. Recent studies assessed the clinical relevance and the prognostic value of the single marker in the Hans algorithm (CD10, MUM1, and BCL6). CD10 is a membrane-associated, neutral endopeptidase that is expressed in a variety of human tissues as well as in the germinal center cells of reactive lymphoid tissues. It is also strongly associated with the GCB-DLBCL subtype. ${ }^{[13]}$ Conflicting results have been reported in the literature with a few studies showing that CD10 expression in DLBCL is associated with inferior survival, ${ }^{[14,15]}$ whereas other reports show that it is associated with better prognosis. ${ }^{[16]}$ However, our analysis showed both correlations were not statistically significant.

MUM1/IRF4 (Interferon Regulatory Factor-4) reflects the final steps of germinal center B-cell maturation into the plasma cell. ${ }^{[17]}$ When the expression of these markers is retained in DLBCL, they are designated as postgerminal center or activated B-cell-like (ABC) subtypes. Studies have shown that MUM1 is associated with unfavorable prognosis in DLBCL. ${ }^{[18-22]}$ However, our analysis showed both correlations were not statistically significant.

BCL6 is a transcription factor that prevents terminal B-cell differentiation. BCL6 is associated with the GCB subtype. BCL6 has emerged as a critical therapeutic target in DLBCL, as the first rationally designed transcription factor inhibitor. ${ }^{[23]}$ Conflicting results have been reported in the literature whether BCL6 expression had no significant association, ${ }^{[24,25]}$ associated with better, ${ }^{[26]}$ or worse ${ }^{[19-21,24,27,28]}$ overall survival in DLBCL. Our study is consistent with the former finding.

BCL2 (B-cell lymphoma 2) protein is an anti-apoptotic protein inhibiting cells from programmed cell death. ${ }^{[29]}$ BCL2 gene amplification and translocations are common mechanisms causing BCL2 protein overexpression in DLBCL. Although both DLBCL subtypes express BCL2, its impact on prognosis may depend on the subtype. ${ }^{[30]}$ BCL2 expression has a significant unfavorable impact on overall survival in GCB-DLBCL but not ABC-DLBCL treated with R-CHOP. ${ }^{[9,31]}$ However, this result is still controversial. ${ }^{[9]}$ Our cohort analysis shows the BCL2 expression is associated with NoR to therapy and longer overall survival; however, this association was not statistically significant. In addition to that, recent data showed that $\mathrm{c}-\mathrm{MYC} / \mathrm{BCL} 2$ protein coexpression in non-GCB subtype constituted a unique group with extremely inferior outcome. ${ }^{[32]}$

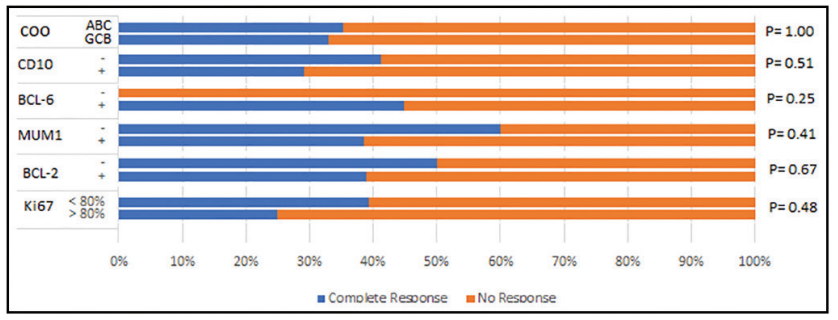

Figure 2: Fisher's exact test of the association between the immunostain expression and response to treatment in patients with DLBCL

\begin{tabular}{|c|c|c|c|c|c|}
\hline Immunostain & Result & $C R(n=14)$ & NoR $(n=27)$ & Total $(n=4 I)$ & $\begin{array}{l}\text { Fisher's exact } \\
\text { test (PValue) }\end{array}$ \\
\hline \multirow[t]{3}{*}{ CDIO $(n=4 I)$} & Positive & $29 \%$ & $71 \%$ & 24 & 0.51 \\
\hline & Negative & $41 \%$ & $59 \%$ & 17 & \\
\hline & Total reported & 14 & 27 & 41 & \\
\hline \multirow{3}{*}{ BCL6 $(n=32)$} & Positive & $45 \%$ & $55 \%$ & 29 & 0.25 \\
\hline & Negative & $0 \%$ & $100 \%$ & 3 & \\
\hline & Total reported & 13 & 19 & 32 & \\
\hline \multirow[t]{3}{*}{ MUMI $(n=23)$} & Positive & $38 \%$ & $62 \%$ & 13 & 0.41 \\
\hline & Negative & $60 \%$ & $40 \%$ & 10 & \\
\hline & Total reported & 11 & 12 & 23 & \\
\hline \multirow[t]{3}{*}{$\mathrm{BCL} 2(n=24)$} & Positive & $39 \%$ & $61 \%$ & 18 & 0.67 \\
\hline & Negative & $50 \%$ & $50 \%$ & 6 & \\
\hline & Total reported & 10 & 14 & 24 & \\
\hline \multirow[t]{3}{*}{ ki67 $(n=40)$} & $>80 \%$ & $25 \%$ & $75 \%$ & 12 & 0.48 \\
\hline & $<80 \%$ & $39 \%$ & $61 \%$ & 28 & \\
\hline & Total reported & 14 & 26 & 40 & \\
\hline \multirow[t]{3}{*}{$\operatorname{coO}(n=4 I)$} & $\mathrm{GCB}$ & $32 \%$ & $68 \%$ & 24 & 1.00 \\
\hline & $A B C$ & $35 \%$ & $65 \%$ & 17 & \\
\hline & Total reported & 14 & 27 & 41 & \\
\hline
\end{tabular}




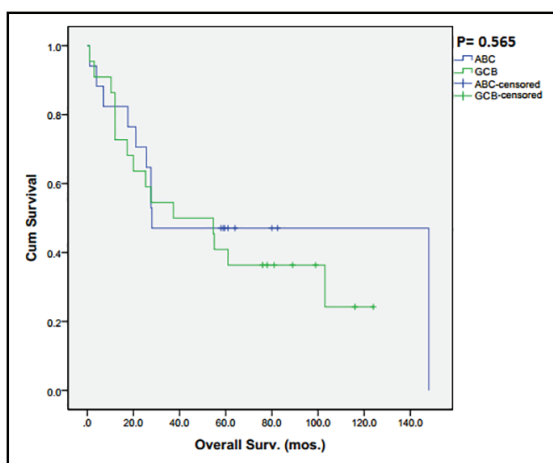

A. Cell of origin

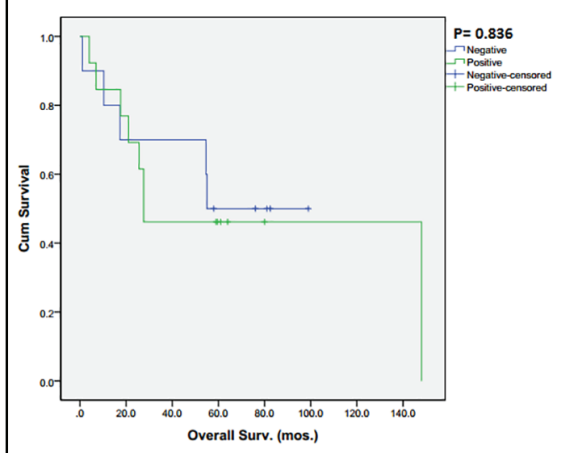

D. MUM1

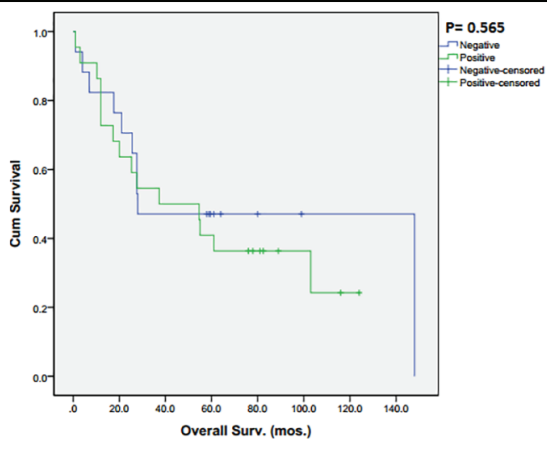

B. CD10

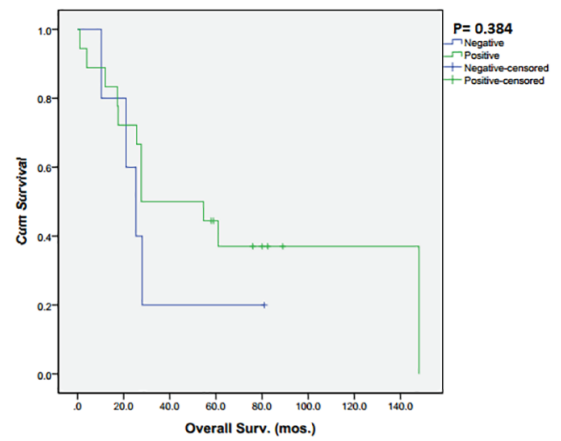

E. BCL-2

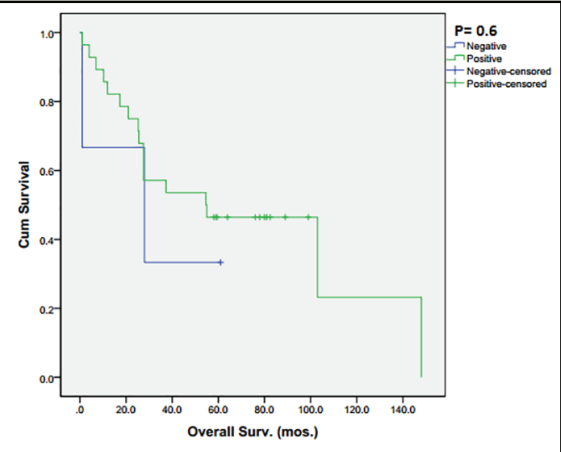

C. BCL-6

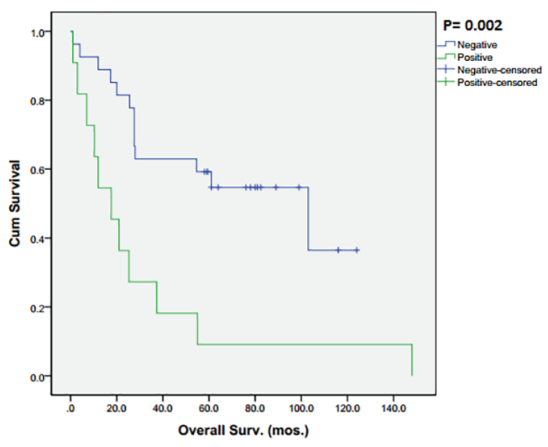

F. $\mathrm{Ki} 67>80 \%$

Figure 3: Kaplan-Meier survival analysis in patients with DLBCL

$\mathrm{CD} 23$, the FC fragment of the IgE receptor, is a surface marker present on follicular dendritic cells and naïve B cells. In lymphoid neoplasms, CD23 is routinely expressed in chronic lymphocytic leukemia/small lymphocytic lymphoma (CLL/ SLL) cases and most mediastinal large B-cell lymphoma cases. CD23 is only present in approximately $16 \%$ of DLBCL cases. ${ }^{[33]}$ Its prognostic value is not well established ${ }^{[33]}$ but has been associated with favorable outcome and better overall survival in several studies. ${ }^{[1,30,33]}$ Our cohort showed the CD 23 immunostaining is only reported in four patients, which preclude further analysis of clinical association.

Ki67 is a nuclear nonhistone protein that is expressed in all phases of the cell cycle except the resting stage (G0). Ki67 has been used in clinical practice as an index to evaluate the proliferative activity of lymphoma with controversial results of its association with DLBCL subtypes. ${ }^{[34,35]}$ High Ki67 expression is a predictive factor of unfavorable survival in DLBCL patients treated with chemotherapy. ${ }^{[1,36-38]}$ Our results showed that high Ki67 proliferation index $(>80 \%)$ showed a statistically significant association with shorter overall survival and nonsignificant association with unfavorable response to treatment. However, other studies showed controversial results of no clinical relevance of Ki67 expression in DLBCL. ${ }^{[39,40]}$ Moreover, the Ki67 expression is thought to be a new unfavorable prognostic factor in
DLBCL patients with bone marrow involvement treated with R-CHOP. ${ }^{[41]}$ We believe the controversial results are based, in part, on the different threshold values used to define high vs. low Ki67 expression status. Spyratos et al. suggested that the Ki67 cutoff should be chosen according to the clinical objectives. If Ki67 is used to exclude patients with slowly proliferating tumors after chemotherapy treatment, a low cutoff will help to avoid overtreatment. On the contrary, if Ki67 is used to identify patients sensitive to chemotherapy treatment, a high cutoff is preferable. ${ }^{[36,42]}$ Moreover, Ki67 has significant interobserver variability between interpreting pathologists, which may also contribute to the conflicting results between studies.

\section{Limitations}

This study is limited by the small number of patients. Also, CD23 immunostain was only reported in four patients so further analysis of association of CD23 with therapy response and overall survival is not reported. Another limitation is the unavailability of molecular gene expression profile (GEF) in our data. The GEP using microarrays has been used to subtype DLBCL into GCB vs. ABC. The microarray analysis reported consistent results with IHC that patients with DLBCL expressing a GEP of GCB have a longer survival than those with a GEP of ABC. ${ }^{[43]}$ However, its complexity and cost make it impracticality of perform 
microarray analysis on every patient with DLBCL and thus the immunohistochemical algorithms are still the most common method. Nevertheless, the strengths of this report are derived from the minimum 5-year follow-up of the patients.

\section{Financial support and sponsorship}

Nil.

\section{Conflicts of interest}

There are no conflicts of interest.

\section{REFERENCES}

1. Swerdlow SH, Campo E, Harris NL, Jaffe ES, Pileri SA, Stein H, Thiele $\mathrm{J}$ (Eds). World Health Organization Classification of Tumors of Hematopoietic and Lymphoid Tissue. Revised 4th ed. Lyon, France: IARC Press; 2017.

2. Sofo-Hafizovic A, Chikha A, Gojak R, Hadzimesic ES. Expression IRF/ MUM1 $>25 \%$ predictor to three-year survival of diffuse large $B$ cell lymphoma in the immunochemotherapy era. Med Arch 2016;70:342-7.

3. Lekakis LJ, Moskowitz CH. The Role of Autologous Stem Cell Transplantation in the Treatment of Diffuse Large B-cell Lymphoma in the Era of CAR-T Cell Therapy. Hemasphere 2019;3:e295. PMID:31976472.

4. Lennert K, Feller AC. Histopathology of Non-Hodgkin's lymphomas (Based on the Updated Kiel Classification) with a section on clinical therapy by M. Engelhard and G. Brittinger. Berlin, Germany: SpringerVerlag; 1992.

5. Hans CP, Weisenburger DD, Greiner TC, Gascoyne RD, Delabie J, Ott G, et al. Confirmation of the molecular classification of diffuse large B-cell lymphoma by immunohistochemistry using a tissue microarray. Blood 2004;103:275-82.

6. Swerdlow SH, Campo E, Harris NL, Jaffe ES, Pileri SA, Stein H, et al. World Health Organization Classification of Tumours of Haematopoietic and Lymphoid Tissues. Lyon, France: IARC Press; 2008.

7. Luo DL, Liu YH, Zhuang HG, Li L, Xu FP, Zhang F, et al. Immunophenotypes and prognosis of diffuse large B-cell lymphoma: A study of 500 cases. Zhonghua Bing Li Xue Za Zhi 2011;40:235-9.

8. Chang CC, McClintock S, Cleveland RP, Trzpuc T, Vesole DH, Logan B, et al. Immunohistochemical expression patterns of germinal center and activation B-cell markers correlate with prognosis in diffuse large B-cell lymphoma. Am J Surg Pathol 2004;28:464-70.

9. Iqbal J, Meyer PN, Smith LM, Johnson NA, Vose JM, Greiner TC, et al. BCL2 predicts survival in germinal center B-cell-like diffuse large B-cell lymphoma treated with CHOP-like therapy and rituximab. Clin Cancer Res 2011;17:7785-95.

10. Schuurman HJ, Huppes W, Verdonck LF, Van Baarlen J, Van Unnik JA. Immunophenotyping of non-Hodgkin's lymphoma. Correlation with relapse-free survival. Am J Pathol 1988;131:102-11.

11. Li ZM, Huang JJ, Xia Y, Zhu YJ, Zhao W, Wei WX, et al. High ki-67 expression in diffuse large B-cell lymphoma patients with non-germinal center subtype indicates limited survival benefit from R-CHOP therapy. Eur J Haematol 2012;88:510-7.

12. Cheson Bruce D. Staging and response assessment in lymphomas: The new Lugano classification. Chin Clin Oncol 2015;4:5.

13. Dogan A, Bagdi E, Munson P, Isaacson GP. CD10 and BCL-6 expression in paraffin sections of normal lymphoid tissue and B-cell lymphomas. Am J Surg Pathol 2000;24:846-52.

14. Uherova P, Ross CW, Schnitzer B, Singleton TP, William G, Finn WG. The clinical significance of CD10 antigen expression in diffuse large B-cell lymphoma. Am J Clin Pathol 2001;115:582-8.
15. Xu Y, McKenna RW, Molberg KH, Kroft SH. Clinicopathologic clinicopathologic analysis of CD10 and bcl-2 diffuse large B-cell lymphoma: Identification of a high-risk subset with coexpression of CD10 and Bcl-2. Am J Clin Pathol 2001;116:183-90.

16. Chang CC, Cleveland RP, Perkins SL. CD10 expression and survival. Am J Clin Pathol 2002;117:660-1.

17. Falini B, Fizzotti M, Pucciarini A, Bigerna B, Marafioti T, Gambacorta M, et al. A monoclonal antibody (MUM1P) detects expression of the MUM1/ IRF4 protein in a subset of germinal center B cells, plasma cells, and activated T cells. Blood 2000;95:2084-92.

18. Muris JJ, Meijer CJ, Vos W, van Krieken JH, Jiwa NM, Ossenkoppele GJ, et al. Immunohistochemical profiling based on bcl-2, CD10 and MUM1 expression improves risk stratification in patients with primary nodal diffuse large B cell lymphoma. J Pathol 2006;208:714-23.

19. Chung KM, Chang ST, Huang WT, Lu CL, Wu HC, Hwang WS, et al. Bcl-6 expression and lactate dehydrogenase level predict prognosis of primary gastric diffuse large B-cell lymphoma. J Formosan Med Assoc $=$ Taiwan yi zhi 2013;112:382-9.

20. Chen Z, Du Z, Chen J, Chen Z, Bao Y, Tang F. Prognostic evaluation of immunohistochemical profiles in diffuse large B-cell lymphoma: A Chinese study. Med Oncol (Northwood, London, England) 2011;28:241-8.

21. Nyman H, Jerkeman M, Karjalainen-Lindsberg ML, Banham AH, Leppä S. Prognostic impact of activated B-cell focused classification in diffuse large B-cell lymphoma patients treated with R-CHOP. Mod Pathol 2009;22:1094-101.

22. Lu TX, Miao Y, Wu JZ, Gong QX, Liang JH, Wang Z, et al. The distinct clinical features and prognosis of the CD $10^{+} \mathrm{MUM} 1^{+}$ and CD10-bcl6-MUM1- diffuse large B-cell lymphoma. Sci Rep 2016;6:20465.

23. Wagner SD, Ahearne M, Ko Ferrigno P. The role of BCL6 in lymphomas and routes to therapy. Br J Haematol 2011;152:3-12.

24. Coutinho R, Clear AJ, Owen A, Wilson A, Matthews J, Lee A, et al. Poor concordance among nine immunohistochemistry classifiers of cell-oforigin for diffuse large B-cell lymphoma: Implications for therapeutic strategies. Clin Cancer Res 2013;19:6686-95.

25. de Jong D, Rosenwald A, Chhanabhai M, Gaulard P, Klapper W, Lee A, et al. Lunenburg Lymphoma Biomarker Consortium. Immunohistochemical prognostic markers in diffuse large B-cell lymphoma: Validation of tissue microarray as a prerequisite for broad clinical applications: A study from the lunenburg lymphoma biomarker consortium. J Clin Oncol 2007;25:805-12.

26. Takeshita M, Iwashita A, Kurihara K, Ikejiri K, Higashi H, Udoh T, et al. Histologic and immunohistologic findings and prognosis of 40 cases of gastric large B-cell lymphoma. Am J Surg Pathol 2000;24:1641-9.

27. Chuang SS, Ye H, Yang SF, Huang WT, Chen HK, Hsieh PP, et al. Perforation predicts poor prognosis in patients with primary intestinal diffuse large B-cell lymphoma. Histopathology 2008;53:432-40.

28. Uccella S, Placidi C, Marchet S, Cergnul M, Proserpio I, Chini C, et al. Bcl6 protein expression, and not the germinal centre immunophenotype, predicts favourable prognosis in a series of primary nodal diffuse large B-cell lymphomas: A single centre experience. Leuk Lymphoma 2008;49:1321-8.

29. Ali HR, Dawson SJ, Blows FM, Provenzano E, Leung S, Nielsen T, et al. A ki67/BCL2 index based on immunohistochemistry is highly prognostic in ER-positive breast cancer. J Pathol 2012;226:97-107.

30. Bachegowda LS, Barta SK. Genetic and molecular targets in lymphoma: Implications for prognosis and treatment. Future Oncol 2014;10:250928.

31. Tang YL, Zhou Y, Cheng LL, Su YZ, Wang CB. BCL2/ki-67 index predict survival in germinal center B-cell-like diffuse large B-cell lymphoma. Oncol Lett 2017;14:3767-73.

32. Teoh CS, Lee SY, Chiang SK, Chew TK, Goh AS. Impact of double expression of C-MYC/BCL2 protein and cell of origin subtypes on the outcome among patients with diffuse large B-cell lymphoma: 
A single Asian center experience. Asian Pac J Cancer Prev 2018;19: 1229-36.

33. Linderoth J, Jerkeman M, Cavallin-Ståhl E, Kvaløy S, Torlakovic E; Nordic Lymphoma Group Study. Immunohistochemical expression of CD23 and CD40 may identify prognostically favorable subgroups of diffuse large B-cell lymphoma: A Nordic lymphoma group study. Clin Cancer Res 2003;9:722-8.

34. Li ZM, Huang JJ, Xia Y, Zhu YJ, Zhao W, Wei WX, et al. High Ki-67 expression in diffuse large B-cell lymphoma patients with non-germinal center subtype indicates limited survival benefit from R-CHOP therapy. Eur J Haematol 2012;88:510-17.

35. Hasselblom S, Ridell B, Sigurdardottir M, Hansson U, Nilsson-Ehle H, Andersson PO. Low rather than high Ki-67 protein expression is an adverse prognostic factor in diffuse large B-cell lymphoma. Leuk Lymphoma 2008;49:1501-9.

36. He X, Chen Z, Fu T, Jin X, Yu T, Liang Y, et al. Ki-67 is a valuable prognostic predictor of lymphoma but its utility varies in lymphomasubtypes: Evidence from a systematic meta-analysis. BMC Cancer 2014;14:153.

37. Broyde A, Boycov O, Strenov Y, Okon E, Shpilberg O, Bairey O. Role and prognostic significance of the Ki-67 index in non-Hodgkin's lymphoma. Am J Hematol 2009;84:338-43.
38. Salles G, de Jong D, Xie W, Rosenwald A, Chhanabhai M, Gaulard P, et al. Prognostic significance of immunohistochemical biomarkers in diffuse large B-cell lymphoma: A study from the Lunenburg Lymphoma Biomarker Consortium. Blood 2011;117:7070-8.

39. Jerkeman M, Anderson H, Dictor M, Kvaloy S, Akerman M, CavallinStahl E. Assessment of biological prognostic factors provides clinically relevant information in patients with diffuse large B-cell lymphoma - a Nordic Lymphoma Group study. Ann Hematol 2004;83:414-9.

40. Colomo L, Lopez-Guillermo A, Perales M, Rives S, Martı' nez A, Bosch F, et al. Clinical impact of the differentiation profile assessed by immunophenotyping in patients with diffuse large B-cell lymphoma. Blood 2003;101:78-84.

41. Song MK, Chung JS, Lee JJ, Yang DH, Kim IS, Shin DH, et al. High Ki-67 expression in involved bone marrow predicts worse clinical outcome in diffuse large B cell lymphoma patients treated with R-CHOP therapy. Int J Hematol 2015;101:140-7.

42. Spyratos F, Ferrero-Pouis M, Trassard M, Hacène K, Phillips E, TubianaHulin M, et al. Correlation between MIB-1 and other proliferation markers: Clinical implications of the MIB-1 cutoff value. Cancer 2002;94:2151-9.

43. Lenz G, Wright G, Dave SS, Xiao W, Powell J, Zhao H, et al. Lymphoma/ Leukemia Molecular Profiling Project. Stromal gene signatures in largeB-cell lymphomas. N Engl J Med 2008;359:2313-23. 